\title{
TGLI1 Allele
}

National Cancer Institute

\section{Source}

National Cancer Institute. tGLI1 Allele. NCI Thesaurus. Code C157117.

Human tGLI1 allele is located in the vicinity of 12 q13.3 and is approximately $12 \mathrm{~kb}$ in length. This allele, which encodes truncated glioma-associated oncogene homolog 1 protein, is involved in the modulation of transcription by RNA polymerase II. Expression of this allele is associated with g lioblastoma multiforme (GBM). 